\title{
Cytogenetic and Molecular Findings in Children with Acute Lymphoblastic Leukemia: Experience of a Single Institution in Argentina
}

\author{
Mariela C. Coccéa Cristina N. Alonso ${ }^{b} \quad$ Jorge G. Rossic Andrea R. Bernasconic \\ Maria A. Rampazzi ${ }^{a} \quad$ Maria S. Felice $^{b}$ Patricia L. Rubio ${ }^{b}$ Silvia Eandi Eberle ${ }^{b}$ \\ Adriana Medinab $^{b}$ Marta S. Gallego ${ }^{a}$ \\ ${ }^{a}$ Cytogenetics Laboratory, Genetics Department, and Departments of b Hematology and Oncology and \\ 'Immunology and Rheumatology, Hospital de Pediatría 'Prof Dr. Juan P. Garrahan', Buenos Aires, Argentina
}

\section{Key Words}

Childhood acute lymphoblastic leukemia · Chromosomal

abnormalities · FISH · RT-PCR

\begin{abstract}
The purpose of the current study was to evaluate the cytogenetic findings in 1,057 children with acute lymphoblastic leukemia (ALL) referred to the cytogenetics laboratory at the Hospital de Pediatría Dr. Juan P. Garrahan, between 1991 and 2014. Chromosomal abnormalities were evaluated by G-banding and FISH. Since December 2002, RT-PCR determinations were systematically carried out for BCR-ABL1, KMT2A-AFF1, ETV6-RUNX1, and TCF3-PBX1 rearrangements in children, adding KMT2A-MLLT3 and KMT2A-MLLT1 in infants. The percentage of abnormalities detected by cytogenetics was $70.1 \%$. Four novel abnormalities, $t(2 ; 8)(p 11.2 ; p 22)$, inv(4) (p16q25), $\mathrm{t}(1 ; 7)(\mathrm{q} 25 ; \mathrm{q} 32)$, and $\mathrm{t}(5 ; 6)(\mathrm{q} 21 ; \mathrm{q} 21)$, were found in this cohort. We compared cytogenetic and RT-PCR results for $B C R-A B L 1, K M T 2 A-A F F 1$ and TCF3-PBX1 rearrangements in 497 children evaluated by both methods. The results were highly concordant $(p<0.7)$, and interestingly, FISH was relevant to confirm G-banding findings that were discordant with RT-PCR studies. This study showed the importance of performing G-banding, FISH and RT-PCR simultaneously to improve the detection of chromosomal abnormalities con-
\end{abstract}

sidering their important value in the diagnosis and prognosis of childhood ALL patients. Finally, to the best of our knowledge, this is the first series of cytogenetic findings in children with ALL reported in Argentina.

(c) 2015 S. Karger AG, Basel

Acute lymphoblastic leukemia (ALL) is a neoplastic disease characterized by the abnormal proliferation of immature lymphoid cells. It is the most frequent hematologic malignancy diagnosed in children, and it represents $\sim 25 \%$ of cancer diagnoses among children younger than 15 years of age [Howlander et al., 2015]. In Argentina, the frequency of acute leukemia in pediatric cancer is $36.7 \%$, of which 79.2\% corresponds to ALL [Moreno and Schvartzman, 2008].

The diagnosis of ALL is based on medical examination, flow cytometric immunophenotyping, cytochemical characteristics, and cytogenetic and molecular findings. ALL is classified as B-cell precursor acute lymphoblastic leukemia (BCP-ALL) and T-cell acute lymphoblastic leukemia (T-ALL), representing $~ 85$ and $15 \%$ of the pediatric ALL cases, respectively. In addition, less than $5 \%$ of acute leukemias are classified as ambiguous lineage acute leukemia (ALAL). Several conventions have been used to define mixed phenotype leukemias, the most recent of which is

\section{KARGER 125}

(c) 2015 S. Karger AG, Base

$1661-8769 / 15 / 0064-0193 \$ 39.50 / 0$

E-Mail karger@karger.com

www.karger.com/msy
Dr. Marta S. Gallego

Cytogenetics Laboratory, Genetics Department

Hospital de Pediatría 'Prof Dr. Juan P. Garrahan'

Combate de los Pozos 1881, Buenos Aires C1245AAM (Argentina)

E-Mail msgallego2003@yahoo.com.ar 
the WHO classification of tumor of hematopoietic and lymphoid tissues, which takes into account the expression of the most specific markers for lineage assignment [Swerdlow et al., 2008].

Nonrandom chromosomal abnormalities (CAs) have been reported in BCP-ALL and T-ALL. The Third International Workshop on Chromosomes in Leukemia [1983] was the first major study that demonstrated the independent prognostic significance of cytogenetic findings at diagnosis in ALL. Subsequently, several studies have been reported on CAs in childhood ALL, which support those first results and revealed important data of further recurrent structural and numerical CAs with a prognostic impact mainly in BCP-ALL. The most relevant examples of the prognostic impact of CAs are $t(9 ; 22)$ (q34;q11.2), t(4;11)(q21;q23) and near haploidy/low hypodiploidy, associated with poor prognosis, while high hyperdiploidy and $\mathrm{t}(12 ; 21)(\mathrm{p} 13 ; \mathrm{q} 22)$ are associated with good prognosis. Conversely, in T-ALL, although recurrent CAs have been reported, they are mostly not associated with prognostic significance.

G-banding is the method commonly carried out to detect CAs. It is relatively inexpensive and covers the complete spectrum of karyotypic abnormalities; however, it is not always successful, and sometimes the chromosomes have a poor quality and indistinct banding for an accurate analysis. The use of FISH and molecular techniques, such as RT-PCR, have led to the detection of cryptic chromosomal rearrangements such as $\mathrm{t}(12 ; 21)(\mathrm{p} 13 ; \mathrm{q} 22) / E T V 6-$ RUNX1 (former TEL-AML1), which is the most common chromosomal rearrangement in BCP-ALL.

Furthermore, some studies have applied spectral karyotyping or multi-FISH complemented by FISH with locus-specific probes, which are techniques that have proved very useful to clarify complex rearrangements. However, these methods are not routinely applied, since they are costly and labor-intensive procedures.

Recently, advances in molecular cytogenetics using array-based technologies have helped to detect additional submicroscopic DNA anomalies; however, this technology is not yet widely applied in clinical cancer diagnosis, mainly due to the inability to detect balanced chromosomal rearrangements.

The aim of this study is to report the CAs in 1,057 cytogenetically evaluable pediatric patients with ALL, studied at our cytogenetics laboratory during 23 years, and to correlate cytogenetic and molecular findings for $B C R$ $A B L 1, K M T 2 A-A F F 1, T C F 3-P B X 1$ rearrangements in cases evaluated by both methods since the incorporation of RT-PCR in December 2002.

\section{Materials and Methods}

From January 1991 to August 2014, 1,482 bone marrow samples from ALL patients were referred to our laboratory for cytogenetic studies; in 1,057 (71.3\%), a successful karyotyping was performed and this constitutes the cohort of the present study.

The mean age of the 1,057 patients was 6.5 years with a median age of 5.5 years (range: 10 days -16 years); 85 were infants ( $<1$ year of age). The male to female ratio was 1.16 (569:488). Twenty-six patients $(2.4 \%)$ had Down syndrome with constitutional trisomy 21 , and one patient had a constitutional Robertsonian translocation $\operatorname{der}(13 ; 15)(\mathrm{q} 10 ; \mathrm{q} 10)$.

Diagnosis of ALL was made following the European Group for the Immunological Classification of Leukemias (EGIL) recommendations until 2008 and subsequently by the WHO classification based on medical examination, flow cytometric immunophenotyping, cytochemical characteristics, and cytogenetic and molecular findings [Bene et al., 1995; Swerdlow et al., 2008].

Bone marrow smears were processed following standard laboratory protocols for cytochemical stains; these included myeloperoxidase (MPO) and Periodic Acid Schiff [Swirsky and Bain, 2006].

Immunophenotyping was performed on bone marrow blasts using the EGIL recommendations. Briefly, aliquots of $3-8 \times 10^{5}$ cells were stained in different tubes with fluorochrome conjugated monoclonal antibodies, appropriately combined, and analyzed by 3 color flow cytometry with a FacSort instrument (Becton Dickinson, San José, Calif., USA), using the CellQuest software. The antibodies used, conjugated either with fluorescein isothiocyanate, phycoerythrin or peridinin chlorophyll protein, were: CD2, CD3, CD4, CD5, CD7, CD8, CD10, CD11b, CD11c, CD13, CD14, CD15, CD16, CD19, CD20, CD21, CD22, CD23, CD25, CD30, CD34, CD38, CD41, CD42, CD45, CD56, CD57, CD61, CD64, HLA-DR, anti $\mu$ chain from Becton Dickinson; from Dako, Denmark: CD79a, TdT and MPO, and from Immunotech, Marseille, France: CD19 Cy5, CD117.

For intracellular staining, cells were permeabilized and fixed using Intraprep Permeabilization reagent (Immunotech).

Cytogenetic studies were performed using G-banding, and when possible, 20 metaphases were analyzed in most cases. Cases with fewer than 20 normal metaphases were classified as unsuccessful and were not included in this cohort. Karyotypes were described according to the International System for Cytogenetic Nomenclature [ISCN, 2013].

In our institution, FISH has been carried out since 1998. Different types of commercially available probes have been used: chromosome painting probes, centromeric probes, subtelomeric probes, and locus-specific identifier probes. The locus-specific identifier panel (Abbott/Vysis) included $B C R-A B L 1$ dual color single fusion and dual color dual fusion translocation probes, KMT2A (former $M L L$ ) dual color break apart rearrangement probe, ETV6-RUNX1 dual color extra signal translocation probe, ETV6 dual color break apart rearrangement probe, TCF3-PBX1 dual color dual fusion translocation probe, and $I G H$ dual color break apart rearrangement probe. All specimens were scored following the scoring criteria described in the manufacturer's manual.

The cytogenetically cryptic abnormality $t(12 ; 21)(\mathrm{p} 13$; q22)/ETV6-RUNX1 was analyzed by FISH in only 22 cases until December 2002; afterwards, RT-PCR studies were systematically performed for all patients to evaluate ETV6-RUNX1 rearrangement. Therefore, its frequency was calculated based on the total of the patients evaluated only by RT-PCR. 
Table 1. Demographic data and frequency of genetic abnormalities in 874 BCP-ALL patients

\begin{tabular}{|c|c|c|c|c|}
\hline Cytogenetic and molecular findings & $\mathrm{n}$ & Frequency, \% & Sex, $M / F$ & Median age \\
\hline \multicolumn{5}{|l|}{ Numerical abnormalities/ploidy } \\
\hline Normal (MN 46) & 244 & 27.9 & $128 / 116$ & 5 ys 5 mo \\
\hline Hypodiploidy (MN 42-45) & 19 & 2.2 & $5 / 14$ & 5 ys 7 mo \\
\hline Low hypodiploidy (MN 33-38) & 5 & 0.6 & $2 / 3$ & 10 ys 5 mo \\
\hline Near haploidy (MN 24-29) & 2 & 0.2 & $2 / 0$ & 4 ys 4 mo \\
\hline Low hyperdiploidy (MN 47-50) & 85 & 9.7 & $51 / 34$ & 6 ys 4 mo \\
\hline High hyperdiploidy (MN 51-65) & 227 & 26.0 & $116 / 111$ & 4 ys 6 mo \\
\hline High ploidy (MN 3n, 4n) & 17 & 1.9 & $10 / 7$ & 6 ys $5 \mathrm{mo}$ \\
\hline \multicolumn{5}{|l|}{ Structural abnormalities } \\
\hline $\mathrm{t}(12 ; 21)(\mathrm{p} 13 ; \mathrm{q} 22) / E T V 6-R U N X 1$ & 75 & $15.2^{\mathrm{a}}$ & $38 / 37$ & 4 ys 5 mo \\
\hline $11 \mathrm{q} 23 /$ KMT2A & 72 & 8.2 & $33 / 39$ & $5 \mathrm{mo}$ \\
\hline $\mathrm{t}(4 ; 11)(\mathrm{q} 21 ; \mathrm{q} 23) / K M T 2 A-A F F 1$ & 42 & 4.8 & $19 / 23$ & $4 \mathrm{mo}$ \\
\hline $\mathrm{t}(11 ; 19)(\mathrm{q} 23 ; \mathrm{p} 13.3) / K M T 2 A-M L L T 1$ & 12 & 1.4 & $5 / 7$ & $7 \mathrm{mo}$ \\
\hline $\mathrm{t}(9 ; 11)(\mathrm{p} 22 ; \mathrm{q} 23) / K M T 2 A-M L L T 3$ & 9 & 1.0 & $4 / 5$ & $5 \mathrm{mo}$ \\
\hline $\mathrm{t}(10 ; 11)(\mathrm{p} 12 ; \mathrm{q} 23) /$ KMT2A-MLLT10 & 3 & 0.3 & $2 / 1$ & $1 \mathrm{y} 1 \mathrm{mo}$ \\
\hline $\mathrm{t}(1 ; 11)(\mathrm{p} 32 ; \mathrm{q} 23) / K M T 2 A-E P S 15$ & 1 & 0.1 & $0 / 1$ & $6 \mathrm{mo}$ \\
\hline $\operatorname{inv}(11)(\mathrm{q} 13 \mathrm{q} 23) / K M T 2 A-B T B D 18$ & 1 & 0.1 & $1 / 0$ & $9 \mathrm{mo}$ \\
\hline $\mathrm{t}(11 ; 17)(\mathrm{q} 23 ; \mathrm{q} 21) / K M T 2 A-M L L T 6$ & 1 & 0.1 & $0 / 1$ & $6 \mathrm{mo}$ \\
\hline $\mathrm{t}(11 ; 22)(\mathrm{q} 23 ; \mathrm{q} 13)$ & 1 & 0.1 & $0 / 1$ & $7 \mathrm{mo}$ \\
\hline $\mathrm{t}(1 ; 19)(\mathrm{q} 23 ; \mathrm{p} 13.3) / T C F 3-P B X 1$ & 53 & 6.0 & $26 / 27$ & 5 ys 5 mo \\
\hline $\mathrm{t}(9 ; 22)(\mathrm{q} 34 ; \mathrm{q} 11.2) / B C R-A B L 1$ & 26 & 3.0 & $21 / 5$ & 9 ys 4 mo \\
\hline iAMP21 & 7 & 0.8 & $1 / 6$ & 6 ys $4 \mathrm{mo}$ \\
\hline $\mathrm{t}(5 ; 14)(\mathrm{q} 31 ; \mathrm{q} 32)$ & 3 & 0.3 & $2 / 1$ & 4 ys $4 \mathrm{mo}$ \\
\hline $\mathrm{t}(8 ; 14)(\mathrm{q} 11.2 ; \mathrm{q} 32)$ & 1 & 0.1 & $0 / 1$ & 4 ys 2 mo \\
\hline $\mathrm{t}(14 ; 19)(\mathrm{q} 32 ; \mathrm{q} 13.1)$ & 1 & 0.1 & $0 / 1$ & 12 ys 6 mo \\
\hline $\operatorname{dic}(9 ; 20)(\mathrm{p} 11 ; \mathrm{q} 11.1)$ & 3 & 0.3 & $2 / 1$ & 1 y $5 \mathrm{mo}$ \\
\hline $\operatorname{dic}(7 ; 9)(\mathrm{p} 11 ; \mathrm{q} 11)$ & 2 & 0.2 & $1 / 1$ & 4 ys 3 mo \\
\hline $\mathrm{t}(8 ; 12)(\mathrm{q} 13 ; \mathrm{p} 13)$ & 1 & 0.1 & $0 / 1$ & 3 ys 2 mo \\
\hline $\mathrm{t}(16 ; 21)(\mathrm{p} 11.2 ; \mathrm{q} 22)$ & 1 & 0.1 & $1 / 0$ & 6 ys $7 \mathrm{mo}$ \\
\hline $\mathrm{t}(17 ; 19)(\mathrm{q} 22 ; \mathrm{p} 13.3)$ & 1 & 0.1 & $1 / 0$ & 1 y $10 \mathrm{mo}$ \\
\hline $\mathrm{t}(6 ; 7)(\mathrm{p} 12 ; \mathrm{p} 21)$ & 1 & 0.1 & $1 / 0$ & 5 ys $3 \mathrm{mo}$ \\
\hline $\mathrm{t}(9 ; 15)(\mathrm{q} 32 ; \mathrm{q} 13)$ & 1 & 0.1 & $1 / 0$ & 7 ys 2 mo \\
\hline Abnormal 9p & 37 & 4.2 & $20 / 17$ & 9 ys 6 mo \\
\hline $\operatorname{del}(6 q)$ & 22 & 2.5 & $14 / 8$ & 5 ys 6 mo \\
\hline $\operatorname{del}(13 q)$ & 13 & 1.5 & $4 / 9$ & 6 ys $7 \mathrm{mo}$ \\
\hline
\end{tabular}

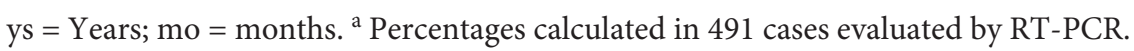

RT-PCR was carried out following BIOMED-1 guidelines and the determination of $B C R-A B L 1$ (p190), BCR-ABL1 (p210), KMT2A-AFF1, ETV6-RUNX1, and TCF3-PBX1 fusion genes were incorporated in December 2002 [van Dongen et al., 1999]. KMT2AMLLT3 and KMT2A-MLLT1 were added in infants with ALL or when KMT2A abnormalities were suspected. In unusual cases, longdistance inverse PCR (LDI-PCR) was performed to further investigate the presence of KMT2A abnormalities [Meyer et al., 2005]. When cytogenetic and molecular studies were discordant, corresponding FISH tests were performed if samples were available.

\section{Statistical Analysis}

The $\chi^{2}$ test was used to compare the percentage of successful karyotypes and the frequency of CAs in different periods of time.
To compare the cytogenetic and molecular findings in cases evaluated by both methods, the 2 -sample proportion test was used; $\mathrm{p}<$ 0.05 was considered significant. The frequencies of recurrent CAs were estimated based on the total number of cases tested within each corresponding group.

\section{Results}

The immunophenotypic analysis revealed 874 BCPALL (82.6\%), 160 T-ALL (15.0\%) and 23 (2.4\%) ALAL. Tables 1-3 show the demographic features (age and sex) 
Table 2. Demographic data and frequency of genetic abnormalities in $160 \mathrm{~T}$-ALL patients

\begin{tabular}{|c|c|c|c|c|}
\hline Cytogenetic and molecular findings & $\mathrm{n}$ & Frequency, \% & Sex, M/F & Median age \\
\hline \multicolumn{5}{|l|}{ Numerical abnormalities/ploidy } \\
\hline Normal (MN 46) & 67 & 41.9 & $53 / 14$ & 9 ys 6 mo \\
\hline Hypodiploidy (MN 45) & 4 & 2.5 & $2 / 2$ & 6 ys 5 mo \\
\hline Low hyperdiploidy (MN 47-50) & 12 & 7.5 & $4 / 8$ & 10 ys $5 \mathrm{mo}$ \\
\hline High hyperdiploidy (MN 51-65) & 2 & 1.25 & $1 / 1$ & 7 ys $10 \mathrm{mo}$ \\
\hline High ploidy (MN 4n) & 1 & 0.6 & $1 / 0$ & 11 ys 6 mo \\
\hline \multicolumn{5}{|l|}{ Structural abnormalities } \\
\hline $\mathrm{t}(11 ; 14)(\mathrm{p} 13 ; \mathrm{q} 11.2)$ & 5 & 3.1 & $5 / 0$ & 12 ys 4 mo \\
\hline $\mathrm{t}(8 ; 14)(\mathrm{q} 24 ; \mathrm{q} 11.2)$ & 5 & 3.1 & $3 / 2$ & 1 y 4 mo \\
\hline $\mathrm{t}(11 ; 14)(\mathrm{p} 15 ; \mathrm{q} 11.2)$ & 1 & 0.6 & $0 / 1$ & 7 ys 8 mo \\
\hline $\mathrm{t}(11 ; 14)(\mathrm{p} 11.2 ; \mathrm{q} 11.2)$ & 1 & 0.6 & $0 / 1$ & 3 ys 1 mo \\
\hline $\mathrm{t}(1 ; 14)(\mathrm{p} 32 ; \mathrm{q} 11.2)$ & 1 & 0.6 & $1 / 0$ & 9 ys 6 mo \\
\hline $\mathrm{t}(9 ; 14)(\mathrm{p} 21 ; \mathrm{q} 11.2)$ & 1 & 0.6 & $1 / 0$ & 5 ys \\
\hline $\operatorname{inv}(14)(\mathrm{q} 11.2 \mathrm{q} 32)$ & 1 & 0.6 & $1 / 0$ & 6 ys 2 mo \\
\hline $\operatorname{del}(14)(q 11.2)$ & 1 & 0.6 & & \\
\hline $\operatorname{inv}(7)(\mathrm{p} 13 \mathrm{q} 34)$ & 2 & 1.25 & $2 / 0$ & 5 ys 6 mo \\
\hline $7 q 32-7 q 34$ & 5 & 3.1 & $4 / 1$ & 12 ys 6 mo \\
\hline $\mathrm{t}(3 ; 12)(\mathrm{p} 21 ; \mathrm{p} 13)$ & 1 & 0.6 & $0 / 1$ & 3 ys 4 mo \\
\hline $\mathrm{t}(7 ; 12)(\mathrm{q} 36 ; \mathrm{p} 13)$ & 1 & 0.6 & $0 / 1$ & $3 \mathrm{mo}$ \\
\hline $\mathrm{t}(8 ; 12)(\mathrm{q} 13 ; \mathrm{p} 13)$ & 1 & 0.6 & $0 / 1$ & 2 ys $4 \mathrm{mo}$ \\
\hline $\mathrm{t}(12 ; 13)(\mathrm{p} 13 ; \mathrm{q} 14)$ & 1 & 0.6 & $0 / 1$ & 3 ys 4 mo \\
\hline $\mathrm{t}(9 ; 17)(\mathrm{q} 34 ; \mathrm{q} 23)$ & 1 & 0.6 & $0 / 1$ & 13 ys $11 \mathrm{mo}$ \\
\hline $\operatorname{del}(6 \mathrm{q})$ & 15 & 9.4 & $11 / 4$ & 6 ys 6 mo \\
\hline $\operatorname{del}(9 p)$ & 8 & 5.0 & $5 / 3$ & 11 ys 6 mo \\
\hline STIL/TAL1 & 19 & $21.1^{\mathrm{a}}$ & $14 / 5$ & 9 ys $7 \mathrm{mo}$ \\
\hline
\end{tabular}

ys $=$ Years; mo = months. ${ }^{\text {a }}$ Percentages calculated in 90 cases evaluated by RT-PCR.

Table 3. Demographic data and frequency of genetic abnormalities in 23 ALAL patients

\begin{tabular}{|c|c|c|c|c|}
\hline Cytogenetic and molecular findings & $\mathrm{n}$ & Frequency, \% & Sex, M/F & Median age \\
\hline \multicolumn{5}{|l|}{ Numerical abnormalities/ploidy } \\
\hline Normal (MN 46) & 3 & 13.0 & $2 / 1$ & 10 ys 2 mo \\
\hline Hypodiploidy (MN 45) & 4 & 17.4 & $2 / 1$ & 4 ys 9 mo \\
\hline Low hyperdiploidy (MN 47) & 1 & 4.3 & $0 / 1$ & $5 \mathrm{mo}$ \\
\hline High hyperdiploidy (MN 55) & 1 & 4.3 & $1 / 0$ & 9 ys 4 mo \\
\hline High ploidy (MN 4n) & 3 & 13.0 & $2 / 1$ & 7 ys $7 \mathrm{mo}$ \\
\hline \multicolumn{5}{|l|}{ Structural abnormalities } \\
\hline $\mathrm{t}(11 ; 19)(\mathrm{q} 23 ; \mathrm{p} 13.3) / K M T 2 A-M L L T 1$ & 2 & 8.7 & $1 / 1$ & $4 \mathrm{mo}$ \\
\hline $\mathrm{t}(9 ; 11)(\mathrm{p} 22 ; \mathrm{q} 23) / K M T 2 A-M L L T 3$ & 1 & 4.3 & $0 / 1$ & $6 \mathrm{mo}$ \\
\hline $\mathrm{t}(1 ; 11)(\mathrm{p} 32 ; \mathrm{q} 23) / K M T 2 A-E P S 15$ & 1 & 4.3 & $0 / 1$ & 6 ys 9 mo \\
\hline $\mathrm{t}(10 ; 11)(\mathrm{p} 12 ; \mathrm{q} 23) / K M T 2 A-M L L T 10$ & 1 & 4.3 & $1 / 0$ & $5 \mathrm{mo}$ \\
\hline $\mathrm{t}(3 ; 19)(\mathrm{p} 21 ; \mathrm{p} 13)$ & 1 & 4.3 & $1 / 0$ & 6 ys 9 mo \\
\hline
\end{tabular}


of the patients at diagnosis and the frequency of CAs and/ or rearrangements detected by conventional cytogenetics, FISH and/or RT-PCR in BCP-ALL, T-ALL and ALAL patients.

\section{Chromosomal Abnormalities and/or Rearrangements} in 874 BCP-ALL Patients

Abnormal karyotypes were observed by G-banding in 630 of the 874 cases $(72.1 \%)$ analyzed.

Numerical Chromosomal Abnormalities/Ploidy

Normal karyotypes were found in 244 cases by Gbanding (27.9\%); 54 were positive for ETV6-RUNX1 by RT-PCR.

Hypodiploidy (modal number (MN) 42-45) was found in 19 cases $(2.2 \%)$. Most of the cases (16/19) had an $\mathrm{MN}$ of 45, with loss of chromosomes 7, 13 or 20 and structural CAs of chromosomes 7, 9 and 12 the most frequent abnormalities found.

Low hypodiploidy (MN 33-38) and near haploidy (MN 24-29) were found in 5 and 2 cases, respectively. Patients with low hypodiploidy had 35 chromosomes and 37 chromosomes in 3 and 2 cases, respectively. One of the cases with MN 35 coexisted with a hyperdiploid line of MN 65.

The 2 cases with near-haploid karyotypes had 27 chromosomes and an extra copy of chromosome 18. Additional chromosomes were 2 chromosomes 21 and 1 marker in one case, and chromosomes 13, 16 and 20 in the other case.

Eighty-five patients (9.7\%) showed low hyperdiploidy (MN 47-50) being 47 the most frequent $\mathrm{MN}(\mathrm{n}=51)$ followed by $48(\mathrm{n}=13), 49(\mathrm{n}=11), 50(\mathrm{n}=9)$, and one case with a range of 47-50 chromosomes. In the different subgroups, trisomy or tetrasomy 21 and trisomy 8 were the CAs most frequently found. In the subgroup of 47 chromosomes, 2 cases each with trisomy 21,2 cases with trisomy 2, 2 cases with trisomy 8 and 1 case with trisomy 16 were detected as a sole abnormality. In 11/85 cases, the chromosome morphology was substandard to identify structural abnormalities. In the remaining 74 cases, structural abnormalities were found in 55 cases $(74.3 \%)$. The most frequent CAs were: abnormal 9p $(\mathrm{n}=37)$, del $(6 \mathrm{q})$ $(\mathrm{n}=22)$, abnormal $12 \mathrm{p}(\mathrm{n}=13)$, monosomy 13/abnormal $13 \mathrm{q}(\mathrm{n}=12)$, and abnormal $17 \mathrm{p}(\mathrm{n}=3)$. Nine cases with MN 47 and 2 cases with MN 48 were ETV6-RUNX1 positive.

High hyperdiploidy, defined as having MN 51-65, was seen in 227 patients (25.9\%). In 55 cases only the MN could be determined because the quality of the chromo-

Acute Lymphoblastic Leukemia in Children somes was substandard to identify all extra chromosomes and/or structural abnormalities. Most of the remaining 172 cases had between 53 and 56 chromosomes with 56 as the most frequent MN. Chromosomes X, 4, 6, 10, 14, 17,18 , and 21 were the most frequent extra chromosomes. Additional structural CAs, in addition to the gain of whole chromosomes, were found in 86 cases $(60.9 \%)$. The most common were partial duplications and triplications of $1 \mathrm{q}$, deletions of $6 \mathrm{q}$ and isochromosomes of $17 \mathrm{q}$ and $7 \mathrm{q}$.

High ploidy, including karyotypes near triploidy $(\mathrm{n}=$ $9)$, near tetraploidy $(n=7)$ and near pentaploidy $(n=1)$, was found in 17 patients (1.9\%), with near triploidy representing $52.9 \%$ of all 17 cases. Structural CAs involved $\operatorname{del}(1 \mathrm{p})$, del $(6 \mathrm{q})$ and additional material in $11 \mathrm{q} 23$ and $16 \mathrm{q}$. The case involving $11 \mathrm{q} 23$ was negative for KMT2A rearrangement. Three cases with near tetraploidy were ETV6RUNX1 positive. Several cases were substandard G-banding and could not be evaluated for the presence of structural abnormalities.

\section{Structural CAs}

The ETV6-RUNX1 rearrangement was the most frequent CA found in BCP-ALL patients. It was detected in 83 patients, 75 by RT-PCR and 8 by FISH, 2 of which showed loss of the green signal corresponding to the wild type of the ETV6 allele. Sixty-two of the 83 patients (74.7\%) had MN 46, 54 cases with normal karyotypes, followed by MN 47-48 ( $\mathrm{n}=12), \mathrm{MN} 45(\mathrm{n}=4), \mathrm{MN} 81-106(\mathrm{n}=3)$, and $\mathrm{MN}>50(\mathrm{n}=1)$. Nine of the 83 patients $(10.8 \%)$ had an abnormality in the short arm of chromosome 12 .

Abnormalities of the $11 \mathrm{q} 23$ region involving the KMT2A gene were detected in 72 cases by G-banding, and/or FISH and/or RT-PCR. Among them, the following aberrations were found: $\mathrm{t}(4 ; 11)(\mathrm{q} 21 ; \mathrm{q} 23) / K M T 2 A$ AFF1 ( $\mathrm{n}=42), \mathrm{t}(11 ; 19)(\mathrm{q} 23 ; \mathrm{p} 13.3) / K M T 2 A-M L L T 1(\mathrm{n}=$ 12), $\mathrm{t}(9 ; 11)(\mathrm{p} 22 ; \mathrm{q} 23) / K M T 2 A-M L L T 3(\mathrm{n}=9), \mathrm{t}(10 ; 11)$ (p12;q23)/KMT2A-MLLT10 (n = 3), t $(1 ; 11)(\mathrm{p} 32 ; \mathrm{q} 23) /$ KMT2A-EPS15 ( $=1), \operatorname{inv}(11)(\mathrm{q} 13 \mathrm{q} 23)(\mathrm{n}=1), \mathrm{t}(11 ; 17)$ (q23;q21)/KMT2A-MLLT6 $(\mathrm{n}=1)$, and $\mathrm{t}(11 ; 22)(\mathrm{q} 23 ; \mathrm{q} 13)$ $(\mathrm{n}=1)$.

Of the 42 cases with $\mathrm{t}(4 ; 11)(\mathrm{q} 21 ; \mathrm{q} 23)$ and/or KMT2AAFF1 rearrangement, we found $\mathrm{t}(4 ; 11)(\mathrm{n}=37)$, variant 3 -way translocations $(\mathrm{n}=2)$, ins $(11 ; 4)(\mathrm{q} 23 ; \mathrm{q} 21 \mathrm{q} 25)(\mathrm{n}=$ $1)$, and 2 cases with normal karyotypes. In all cases, KMT2A-AFF1 rearrangement was detected by FISH and/ or RT-PCR.

Twelve cases showed $t(11 ; 19)(q 23 ; p 13.3)$ and/or the KMT2A-MLLT1 rearrangement. Of them, G-banding showed $\mathrm{t}(11 ; 19)$ in 10 cases, but the KMT2A-MLLT1 re- 
arrangement was identified by FISH and RT-PCR in 2 additional cases. One of these cases had a complex karyotype that showed alterations of 11q23 and 19p13.3 regions, but did not have the typical $t(11 ; 19)$, and the other one had additional material on the short arm of chromosome 19 that could not be identified.

Translocation $(9 ; 11)(\mathrm{p} 22 ; \mathrm{q} 23)$ and/or KMT2AMLLT3 rearrangement were found in 9 cases. G-banding revealed $\mathrm{t}(9 ; 11)(\mathrm{p} 22 ; \mathrm{q} 23)(\mathrm{n}=5)$ and one variant translocation $(\mathrm{n}=1)$. Of the remaining 3 cases, one case showed a complex karyotype which involved only chromosome 9 , and 2 cases showed normal karyotypes. In these 3 cases, the KMT2A-MLLT3 rearrangement was detected by RTPCR and/or FISH.

CAs 10;11 rearrangements and/or KMT2A-MLLT10 were found in 3 cases; one case had $\mathrm{t}(10 ; 11)(\mathrm{p} 12 ; \mathrm{q} 23)$, another case had at $(7 ; 11)(\mathrm{q} 22 ; \mathrm{q} 23)$ and a cryptic ins $(10$; 11)(p12;q23q23) was detected by FISH. The third case had an ins $(10 ; 11)(\mathrm{p} 12 ; \mathrm{q} 23 \mathrm{q} 13)$. The transcript KMT2AMLLT10 was confirmed by RT-PCR in all cases.

Translocation $(1 ; 19)(\mathrm{q} 23 ; \mathrm{p} 13.3) /$ derivative 19 and/or TCF3-PBX1 rearrangement were detected in 53 cases: 23 only by cytogenetics, 3 only by RT-PCR and 27, by both techniques. Eighteen out of the 50 cases detected by cytogenetics showed a balanced $\mathrm{t}(1 ; 19)(\mathrm{q} 23 ; \mathrm{p} 13.3)$, and 32 cases showed the unbalanced $\operatorname{der}(19) t(1 ; 19)$. One case had an abnormal karyotype with a $9 \mathrm{p}$ deletion as a sole abnormality, and FISH revealed a cryptic ins $(19 ; 1)$ (p13.3;q23q23). RT-PCR confirmed the presence of TCF3-PBX1 rearrangement. Of note, in one case with $t(1$; 19 ) and in 2 cases with derivative 19 detected by G-banding and confirmed by FISH, the presence of the TCF3$P B X 1$ transcript was not detected by RT-PCR. One of these cases was hyperdiploid $>50$. The $t(1 ; 19)$ or the derivative 19 were the only abnormalities in 13 and 18 cases, respectively. Additional CAs to $t(1 ; 19)$ and the derivative 19 were unbalanced translocations $(\mathrm{n}=3)$, marker chromosomes $(n=3)$, del $(6 q)(n=3), i(9 q)(n=2)$, and $i(7 q)$ $(\mathrm{n}=2)$. In the 3 cases with normal karyotypes and positive RT-PCR for TCF3-PBX1, we could not perform FISH analysis since there were no samples available.

Translocation $(9 ; 22)(\mathrm{q} 34 ; \mathrm{q} 11.2) / B C R-A B L 1$ were observed in 26 patients, 6 only by G-banding and 19 by both, G-banding and RT-PCR. In addition, FISH revealed the $B C R-A B L 1$ fusion in interphase nuclei in one case with a normal karyotype and positive RT-PCR. Among the 25 cases detected by G-banding, 12 had the standard translocation $\mathrm{t}(9 ; 22)$ as a sole abnormality, one case had a 3-way translocation which involved chromosomes 9, 17 and 22 , and the remaining 12 cases showed additional ab- normalities that included a second Philadelphia chromosome, an isochromosome of the derivative 9 of the $t(9 ; 22)$, several random translocations and marker chromosomes. Twenty-three karyotypes were peseudodiploid and 2 hyperdiploid.

Intrachromosomal amplification of chromosome 21 (iAMP21) was suspected in 7 patients in whom an abnormal chromosome 21 was observed by G-banding. In these cases, iAMP21 was confirmed by FISH using the ETV6$R U N X 1$ probe that showed 5 or more $R U N X 1$ signals. The abnormal chromosome 21 included tandem triplication, rings, additional material in the 21 chromosome, and markers suspected of being iAMP21.

CAs of 14q32/IGH@ rearrangements were found in 6 cases: $\mathrm{t}(5 ; 14)(\mathrm{q} 31 ; \mathrm{q} 32)(\mathrm{n}=3), \mathrm{t}(8 ; 14)(\mathrm{q} 11.2 ; \mathrm{q} 32)(\mathrm{n}=$ $1), \mathrm{t}(14 ; 19)(\mathrm{q} 32 ; \mathrm{q} 13.1)(\mathrm{n}=1)$, and one with additional material in $14 \mathrm{q} 32$ associated with a hyperdiploid karyotype. FISH showed split signal in all cases, but in the case with additional material in 14q32, the partner could not be identified.

In addition, there was a case with $\mathrm{t}(9 ; 22)(\mathrm{q} 34 ; \mathrm{q} 11.2)$ associated with $\mathrm{t}(8 ; 14)(\mathrm{q} 11.2 ; \mathrm{q} 32)$, which was included in the group of $B C R-A B L 1$ patients.

A dicentric chromosome between chromosome 9 and another chromosome was found in 5 cases: $\operatorname{dic}(9 ; 20)$ $(\mathrm{p} 11 ; \mathrm{q} 11.1)(\mathrm{n}=3)$ and $\operatorname{dic}(7 ; 9)(\mathrm{p} 11 ; \mathrm{q} 11)(\mathrm{n}=2)$. All cases were confirmed by FISH using centromeric probes for the involved chromosomes. Two of the cases with $\operatorname{dic}(9$; $20)$ and one with $\operatorname{dic}(7 ; 9)$ displayed dicentric chromosomes as the only abnormality. The remaining 2 cases coexisted with random CAs.

We found 6 rare, recurrent translocations, each of them in one patient. They were: $\mathrm{t}(8 ; 12)(\mathrm{q} 13 ; \mathrm{p} 13), \mathrm{t}(16 ; 21)$ (p11.2;q22), t(17;19)(q22;p13.3), t(6;7)(p12;p21), t(8;14) (q11; $\mathrm{q} 32)$, and $\mathrm{t}(9 ; 15)(\mathrm{q} 32 ; \mathrm{q} 13)$.

Additional structural CAs were: abnormal 9p $(n=37)$, including $\operatorname{del}(9 \mathrm{p}), \mathrm{i}(9 \mathrm{q})$ and $\operatorname{add}(9 \mathrm{p}) ; \operatorname{del}(6 \mathrm{q})(\mathrm{n}=22)$; $\operatorname{del}(13 q)(n=12)$; abnormal $17 \mathrm{p}(\mathrm{n}=3)$, and random CAs. Most of them were present together in the same karyotype such as $\operatorname{del}(6 q)$ and $\operatorname{del}(9 p)$ or were associated with other CAs.

\section{Chromosomal Abnormalities in 160 T-ALL Patients}

Abnormal karyotypes were observed in 93 (58.1\%) of the 160 patients with T-ALL.

\section{Numerical CAs}

Numerical CAs included: MN $45(\mathrm{n}=4), \mathrm{MN} 47-50$ $(\mathrm{n}=12), \mathrm{MN}>50(\mathrm{n}=2)$, and $\mathrm{MN}$ near tetraploidy $(\mathrm{n}=1)$. The most common numerical CA was trisomy $8(n=4)$. 
Table 4. Novel chromosomal abnormalities in our series

\begin{tabular}{lllll}
\hline Chromosomal abnormalities & Immunophenotype & $\mathrm{n}$ & Sex, M/F & Age \\
\hline $\mathrm{t}(2 ; 8)(\mathrm{p} 11.2 ; \mathrm{p} 22)$ & BCP & 1 & $0 / 1$ & $7 \mathrm{ys} 2 \mathrm{mo}$ \\
$\operatorname{inv}(4)(\mathrm{p} 16 \mathrm{q} 25)$ & BCP & 1 & $1 / 0$ & $16 \mathrm{ys} 7 \mathrm{mo}$ \\
$\mathrm{t}(1 ; 7)(\mathrm{q} 25 ; \mathrm{q} 32)$ & BCP & 2 & $2 / 0$ & $15 \mathrm{ys} 3 \mathrm{mo} / 11 \mathrm{ys} 1 \mathrm{mo}$ \\
$\mathrm{t}(5 ; 6)(\mathrm{q} 21 ; \mathrm{q} 21)$ & $\mathrm{T}$ & 1 & $1 / 0$ & $13 \mathrm{ys} 7 \mathrm{mo}$
\end{tabular}

ys $=$ Years; $\mathrm{mo}=$ months.

Structural CAs

The most frequent CAs involved breakpoints at 14q11.2, 7q34 and 7q32. Among the 14q11.2 abnormalities we found $\mathrm{t}(11 ; 14)(\mathrm{p} 13 ; \mathrm{q} 11.2)(\mathrm{n}=5), \mathrm{t}(8 ; 14)(\mathrm{q} 24$; q11.2) $(\mathrm{n}=5)$, and $\mathrm{t}(11 ; 14)(\mathrm{p} 15 ; \mathrm{q} 11.2), \mathrm{t}(11 ; 14)(\mathrm{p} 11.2$; $\mathrm{q} 11.2), \mathrm{t}(1 ; 14)(\mathrm{p} 32 ; \mathrm{q} 11.2), \mathrm{t}(9 ; 14)(\mathrm{p} 21 ; \mathrm{q} 11.2), \quad \operatorname{inv}(14)$ (q11.2q32), and del(14)(q11.2) each in one case. The CAs involving chromosome 7 were: $\operatorname{inv}(7)(\mathrm{p} 13 \mathrm{q} 34)(\mathrm{n}=2)$, abnormal 7q32 ( $\mathrm{n}=3)$, abnormal 7q34 $(\mathrm{n}=1)$, and abnormal 7p13 (n=1).

We also found 5 individual cases with rarely reported recurrent translocations: $\mathrm{t}(3 ; 12)(\mathrm{p} 21 ; \mathrm{p} 13), \mathrm{t}(7 ; 12)(\mathrm{q} 36$; $\mathrm{p} 13), \mathrm{t}(8 ; 12)(\mathrm{q} 13 ; \mathrm{p} 13), \mathrm{t}(9 ; 17)(\mathrm{q} 34 ; \mathrm{q} 23)$, and $\mathrm{t}(12 ; 13)(\mathrm{p} 13$; q14). FISH revealed ETV6 rearrangements in every case that involved the $12 \mathrm{p} 13$ region.

Additional structural CAs were: $\operatorname{del}(6 \mathrm{q})(\mathrm{n}=15), \operatorname{del}(9 \mathrm{p})$ $(\mathrm{n}=8)$, del(11q23) $(\mathrm{n}=5)$, abnormal $12 \mathrm{p}(\mathrm{n}=4)$, abnormal 1q $(n=3), \operatorname{del}(11 \mathrm{q} 21)(\mathrm{n}=3), \operatorname{dup}(1 \mathrm{q})(\mathrm{n}=2), \operatorname{del}(3 \mathrm{q})(\mathrm{n}=$ $1)$, del $(17 \mathrm{p})(\mathrm{n}=1)$, and other random CAs $(\mathrm{n}=22)$.

Molecular studies in 90 T-ALL tested revealed 19 cases with STIL-TAL1. Among them we found: low hyperdiploidy MN 47-50 ( $\mathrm{n}=2)$, normal karyotypes $(\mathrm{n}=8)$, pseudodiploid karyotypes with $\operatorname{del}(6 \mathrm{q})(\mathrm{n}=3), \mathrm{t}(11 ; 14)$ $(\mathrm{p} 13 ; \mathrm{q} 11.2)(\mathrm{n}=2), \mathrm{t}(11 ; 14)(\mathrm{p} 15 ; \mathrm{q} 11.2)(\mathrm{n}=1), \mathrm{t}(8 ; 14)$ $(\mathrm{q} 24 ; \mathrm{q} 11.2)(\mathrm{n}=1)$, and random CAs $(\mathrm{n}=2)$.

\section{Chromosomal Abnormalities in 23 ALAL Patients}

Twenty of the 23 patients (86.9\%) with ALAL had an abnormal karyotype. Numerical abnormalities included: MN $45(\mathrm{n}=4)$, MN $47(\mathrm{n}=1)$, MN $55(\mathrm{n}=1)$, and near tetraploidy $(\mathrm{n}=3)$. Recurrent translocations found in pseudodiploid karyotypes included: $\mathrm{t}(11 ; 19)(\mathrm{q} 23 ; \mathrm{p} 13.3)$ $(\mathrm{n}=2), \mathrm{t}(9 ; 11)(\mathrm{p} 22 ; \mathrm{q} 23)(\mathrm{n}=1), \mathrm{t}(1 ; 11)(\mathrm{p} 32 ; \mathrm{q} 23)(\mathrm{n}=1)$, and $\mathrm{t}(3 ; 19)(\mathrm{p} 21 ; \mathrm{p} 13)(\mathrm{n}=1)$. FISH analysis showed $K M$ T2A rearrangement in a case with a normal karyotype in which RT-PCR revealed the KMT2A-MLLT10 fusion. Other structural CAs were: $\operatorname{del}(6 \mathrm{q})(\mathrm{n}=2), \operatorname{del}(7 \mathrm{q})(\mathrm{n}=$ $1)$ and random CAs $(n=2)$.

\section{Novel Chromosomal Abnormalities}

In this series, we found 4 translocations which, to our knowledge, have not been previously described in the literature: $\mathrm{t}(2 ; 8)(\mathrm{p} 11.2 ; \mathrm{p} 22)(\mathrm{n}=1), \operatorname{inv}(4)(\mathrm{p} 16 \mathrm{q} 25)(\mathrm{n}=1)$, $\mathrm{t}(1 ; 7)(\mathrm{q} 25 ; \mathrm{q} 32)(\mathrm{n}=2)$, and $\mathrm{t}(5 ; 6)(\mathrm{q} 21 ; \mathrm{q} 21)(\mathrm{n}=1)$. The first 3 CAs belong to BCP-ALL and the latter to T-ALL patients (table 4).

\section{Correlation between Cytogenetic and Molecular Findings}

The cohort was divided into 2 groups of 485 and 572 patients each, in order to compare the frequency of CAs in cases evaluated only by cytogenetic techniques or by both, cytogenetic and molecular studies. The frequency of CAs was 73.4\% (356/485) and 77.1\% (441/572) (p < 0.12 ) in each group of patients.

Furthermore, to compare cytogenetic and molecular results for $B C R-A B L 1$ (p190)/(p210), KMT2A-AFF1, and TCF3-PBX1 rearrangements, we included 497/572 patients in whom cytogenetics (G-banding and/or FISH) and molecular studies were performed. Four cases had discrepant results in patients with $\mathrm{t}(4 ; 11)(\mathrm{q} 21 ; \mathrm{q} 23)$ and $\mathrm{t}(1 ; 19)$ (q23;p13.3)/derivative 19, identified by G-banding in 1 and 3 cases, respectively, in whom the fusion transcripts were not detected by RT-PCR. In the case with $\mathrm{t}(4$; 11)(q21;q23), the rearrangement was confirmed by LDIPCR.

\section{Discussion}

Cytogenetic analyses have been very useful to identify acquired chromosomal aberrations and have contributed to the discovery of several genes whose fusion or activation has an important role in the neoplastic process. Approximately $75 \%$ of childhood ALL cases harbor CAs detected by conventional cytogenetics and FISH. However, the percentage varies from 55 up to $89 \%$ in different series 
depending on the number of patients studied, the year they were reported, and the populations where they have been studied [Chessels et al., 1997; Andreasson et al., 2000; Forestier et al., 2000; De Braekeleer et al., 2010; Moorman et al., 2010; Gil et al., 2013].

We report the cytogenetic findings in 1,057 children with ALL studied in our center, spanning a period of 23 years. The percentage of successfully performed karyotyping improved progressively, with a mean of $60.5 \%$ in the first 12 years and $83.4 \%$ in the last 11 years $(\mathrm{p}<$ 0.00001 ), mostly due to modifications introduced in the collection of bone marrow samples and in processing methods in order to optimize the results.

The use of FISH studies introduced in our laboratory in 1998 has been very useful to detect cryptic rearrangements, and the subsequent incorporation of the RT-PCR technique increased the detection of CAs from 73 to $77 \%$ in 572 patients in which all the techniques were applied $(\mathrm{p}<0.12)$.

Among numerical recurrent abnormalities in BCPALL, MN 51-65 was the most common CA found in our series. The chromosomes involved and the percentage of cases with structural CAs (61.4\%) are similar to data reported in other studies [Paulsson and Johansson, 2009]. Conversely, the frequency of low hypodiploidy $(0.6 \%)$ and near haploidy $(0.2 \%)$ was lower than the $1 \%$ reported in previous studies [Chessels et al., 1997; De Braekeleer et al., 2010; Moorman et al., 2010]. This may be due to the fact that the hypodiploid clone might be too small to be detected or may undergo endoreduplication, doubling the number of chromosomes, resulting in a near diploid or hyperdiploid karyotype.

Translocation $(12 ; 21)(\mathrm{p} 13 ; \mathrm{q} 22) / E T V 6-R U N X 1$ was found in $15 \%$ of the cases in a previous report [Alonso et al., 2012]; this percentage is lower than others reported in comparable studies, although geographic and/or ethnic variations in the frequency of this rearrangement has been described [Forestier et al., 2000; Douet-Guilbert et al., 2003; Moorman et al., 2010]. Of note, a FISH-detected deletion of the wild-type allele in 2 out of 8 positive cases, showing the importance of this technique in providing additional information that is given by molecular studies.

Chromosomal rearrangements involving the KMT2A gene were found in $8.2 \%$ of the cases $(72 / 874)$ and increased to $68.2 \%(58 / 85)$ in infants. Translocation $\mathrm{t}(4 ; 11)$ (q21;q23)/KMT2A-AFF1 was the most frequent rearrangement found. Interestingly, one case had a translocation $\mathrm{t}(4 ; 11)$ revealed by G-banding and confirmed by FISH, but the KMT2A-AFF1 transcript was not detected by RT-PCR. In this case, molecular studies using LDI-
PCR revealed the presence of a reciprocal fusion gene that consisted of AFF1 intron 10 fused with KMT2A intron 3; therefore, the corresponding fusion transcript would result in the fusion of $K M T 2 A$ exon 3 to $A F F 1$ exon 11.This transcript is not detected by the standard primers used in routine RT-PCR studies, since it does not involve the classical breakpoint region of KMT2A [van Dongen et al., 1999].

Another interesting finding was an inv(11)(q12q23) detected by conventional cytogenetics and FISH. This led us to a novel fusion transcript identified by LDI-PCR which consisted of KMT2A fused with the BTBD18 gene on chromosome region 11q12 [Alonso et al., 2010]. Therefore, our results confirm, as other authors have suggested, that the break apart dual color FISH probe is the most appropriate method to detect KMT2A rearrangements; it also detects $3^{\prime}$ deletions and cryptic insertions. FISH for evaluation of KMT2A rearrangements should be used in all cases of acute leukemia with a normal karyotype or in those cases with suspected 11q23 abnormalities, and if necessary, further molecular cytogenetic and genomic PCR methods should be used [De Braekeleer et al., 2011].

iAMP21 with multiple copies of the RUNX1 gene was identified in $0.9 \%$ of the patients in the present study. This rare entity is found in $1.5-4.5 \%$ of patients younger than 20 years of age ( $2 \%$ on average) [Harrison et al., 2014; Heerema et al., 2013]. As only structural rearrangements involving chromosome 21 that were suspected of amplification of the RUNX1 gene by G-banding were studied by FISH, the frequency is lower than that found in other reports, where FISH screening was systematically performed for the detection of the cryptic $t(12 ; 21)$ with the ETV6-RUNX1 probe.

In our study, rearrangements involving the immunoglobulin heavy chain locus (IGH@) were found in $0.8 \%$ of the cases; of them, 3 cases were translocation $\mathrm{t}(5 ; 14)$ (q31;q32), and 2 of them were associated with hypereosinophilia, which is a characteristic feature described in these patients [Gallego et al., 2012]. Our findings confirm the low frequency of these rearrangements, the diversity of the partner chromosome regions such as $19 \mathrm{p} 13$ and $8 \mathrm{q} 11$, and the association of $\mathrm{t}(8 ; 14)(\mathrm{q} 11 ; \mathrm{q} 32)$ with $\mathrm{t}(9 ; 22)$ (q34;q11.2). Furthermore, we found another case with the association of $t(8 ; 14)$ with Down syndrome, as has been previously described.

The incidence of IGH@ translocations remains unknown, and FISH has been recommended for its detection due to the cryptic nature of these abnormalities [Jeffries et al., 2014]. A recent study reported that adult pa- 
tientswithIGH@ translocations have an adverse outcome, although this translocation is not an independent prognostic factor in children [Russell et al., 2014].

Interestingly, we found $\operatorname{dic}(9 ; 20)(\mathrm{p} 11 ; \mathrm{q} 11.1)$ and $\operatorname{dic}(7$; 9)(p11;q11), all of which were confirmed by FISH. Our series has a lower frequency of dicentric chromosomes compared with previously reported data [Moorman et al., 2010]. In addition, even though aberrations involving the long arm of chromosomes 9 and 12 were suspected of being dicentric, we could not confirm such abnormalities.

Furthermore, in this series we found a $58.1 \%$ of CAs in T-ALL patients, which is in line with previous data reported [Schneider et al., 2000]. We also found rare, recurrent translocations and several common CAs in BCP, $\mathrm{T}$ and ALAL lineages. Interestingly, among BCP-ALL, we found a case of $t(16 ; 21)(\mathrm{p} 11.2 ; \mathrm{q} 22)$, which is the fourth case of this translocation in childhood ALL reported in the literature [Coccé et al., 2015].

Another finding in BCP-ALL in our series was the translocation $\mathrm{t}(9 ; 15)(\mathrm{q} 34 ; \mathrm{q} 15)$. Rearrangements of band $15 \mathrm{q} 13 \mathrm{q} 15$ are very rare in ALL, and it has been reported in $1 \%$ of the cases [Heerema et al., 2002].

We also found several cases involving region $19 \mathrm{p} 13$ besides $t(1 ; 19)(q 23 ; p 13.3)$ and $t(11 ; 19)(q 23 ; p 13.3)$, such as $\mathrm{t}(3 ; 19)(\mathrm{p} 21 ; \mathrm{p} 13), \mathrm{t}(17 ; 19)(\mathrm{q} 22 ; \mathrm{p} 13.3)$ and 7 cases with additional material in $19 \mathrm{p} 13$. The $19 \mathrm{p} 13$ abnormality is a nonrandom CA in patients with ALL. Translocation $t(3$; 19)(p21;p13) was found in this cohort in a patient with ambiguous lineage and, to our knowledge, it has been previously reported only in 2 children with ALL and in one adult with AML, suggesting that this CA could affect the germline [Zhu et al., 2007; Mitelman Database, 2015].

We also identified a patient with the rare translocation $\mathrm{t}(9 ; 17)(\mathrm{q} 34 ; \mathrm{q} 23)$ in T cells, which to our knowledge, is the fourth case reported in T-ALL patients [Mitelman Database, 2015].

Actually, band $12 \mathrm{p} 13$ is one of the most common chromosomal regions involved in CAs in leukemia, mostly resulting in the ETV6 gene rearrangement. Up to date, 48 chromosomal bands have been identified to be involved in ETV6 translocations, insertions or inversions, and 30 ETV6 partner genes have been molecularly characterized [De Brakeleer et al., 2012]. In the present series, we found 4 rare, recurrent translocations involving $12 \mathrm{p} 13$ rearrangement, namely $\mathrm{t}(3 ; 12)(\mathrm{p} 21 ; \mathrm{p} 13), \mathrm{t}(7 ; 12)(\mathrm{q} 36 ; \mathrm{p} 13)$, $\mathrm{t}(12 ; 13)(\mathrm{p} 13 ; \mathrm{q} 14)$, and $\mathrm{t}(8 ; 12)(\mathrm{q} 13 ; \mathrm{p} 13)$ [Gallego et al., 2008]. They had been previously reported in 2, 2, 10, and 3 cases of ALL, respectively [Mitelman Database, 2015]. These translocations presented ETV6 rearrangements and early $\mathrm{T}$ immunophenotype.

Acute Lymphoblastic Leukemia in Children
The 21 patients found with high ploidy (2\%) confirm its low frequency in ALL and the heterogeneity regarding the immunophenotype of this subset, as reported in the literature [Lemez et al., 2010]. Deletions of $6 q$ and $9 p$ were found in all lineages, mainly associated with other CAs. However, del(9p) as a sole abnormality was found in $42.5 \%$ of the cases, suggesting that directly or indirectly it is involved in leukemogenesis.

The following novel CAs, not previously reported, were identified in the present study: $\mathrm{t}(2 ; 8)(\mathrm{p} 11.2 ; \mathrm{p} 22)$ $(\mathrm{n}=1), \operatorname{inv}(4)(\mathrm{p} 16 \mathrm{q} 25)(\mathrm{n}=1), \mathrm{t}(1 ; 7)(\mathrm{q} 25 ; \mathrm{q} 32)(\mathrm{n}=2)$, and $\mathrm{t}(5 ; 6)(\mathrm{q} 21 ; \mathrm{q} 21)(\mathrm{n}=1)$ (table 4$)$. We focused our search on the genes described in the breakpoints involved in these novel findings and their potential relation to cancer. We found the following genes: $C A P G$ in $2 \mathrm{p} 11.2$; DLC1, NAT2, MTSS1 and TUSC3 in 8p22; MED28 in 4p16; $A B L 2$ and TPR in $1 \mathrm{q} 25 ; R A B 9 B P 1$ in $5 \mathrm{q} 21.2$, and PDSS2 in 6q21. All of them are associated with different types of cancers. It is remarkable to have found the $A B L 2$ gene in 1q25, which is a proto-oncogene whose protein is a non-receptor tyrosine kinase, and the TPR gene in the same region; its extreme $5^{\prime}$ end fuses with several different kinase genes in some neoplasias and could be involved in leukemogenesis mechanisms [Huret et al., 2013]. Moreover, $A B L 2$ has been associated with the $\mathrm{Ph}$-like subgroup of ALL, which is a targetable kinase-activating lesion [Roberts et al., 2014]. Further studies would determine if these CAs could be actionable targets for these lesions.

Another aim of this study was to compare cytogenetic and molecular results for $B C R-A B L 1, K M T 2 A$ $A F F 1$ and TCF3-PBX1 rearrangements. In the 497 patients in whom we could compare cytogenetic and RTPCR studies, we had concurrent results with a few exceptions ( $\mathrm{p}<0.7)$. FISH was of benefit in detecting cryptic abnormalities such as BCR-ABL1, KMT2AMLLT1 and KMT2A-MLLT3 rearrangements in cases with normal karyotypes. Furthermore, we need to point out that FISH confirmed the presence of $\mathrm{t}(4 ; 11)(\mathrm{q} 21 ; \mathrm{q} 23)$ and $\mathrm{t}(1 ; 19)$ (q23;p13.3)/derivative 19, identified by Gbanding in 1 and 3 cases, respectively, in which the fusion transcripts could not be detected by RT-PCR. It could be possible that in these cases the fusion transcripts do not involve the classical breakpoints which are detected by the standard primers used in PCR [van Dongen et al., 1999], as it was confirmed by LDI-PCR in the case with $\mathrm{t}(4 ; 11)(\mathrm{q} 21 ; \mathrm{q} 23)$.

In conclusion, this large series of cytogenetic studies has confirmed the results of previous data regarding type and frequency of CAs in pediatric ALL. In addition, more 
novel CAs were found in this cohort which have not been previously described in ALL.

Finally, to the best of our knowledge, the present study is the first comprehensive series of cytogenetic findings in children with ALL reported in Argentina.

It shows, as in the case of previous reports [Soszynska et al., 2008; Olde Nordkamp et al., 2009; Harrison et al., 2010], that the detection of CAs using conventional cytogenetics is distinctly improved by FISH and/or RTPCR methods. These techniques should be used simultaneously to improve accuracy in the identification of the main CAs, since they are useful tools with diagnostic and prognostic value in the management of children with ALL.

\section{Acknowledgments}

We thank Dr. Susana Raimondi for her critical review of this study and her constant help, and Miss Fabiana Travella for her valuable revision of the manuscript.

\section{Statement of Ethics}

This study has been approved by the Garrahan Hospital Committee of Ethics.

\section{Disclosure Statement}

The authors declare neither competing financial interests nor conflicts of interest.

\section{References}

-Alonso CN, Meyer C, Gallego MS, Rossi JG, Mansini AP, et al: BTBD18: a novel MLL partner gene in an infant with acute lymphoblastic leukemia and inv(11)(q13;q23). Leuk Res 34:e294-e296 (2010).

-Alonso CN, Gallego MS, Rossi JG, Medina A, Rubio PL, et al: RT-PCR diagnosis of recurrent rearrangements in pediatric acute lymphoblastic leukemia in Argentina. Leuk Res 36: 704-708 (2012).

-Andreasson P, Höglund M, Békássy AN, Garwicz S, Heldrup J, et al: Cytogenetic and FISH studies of a single center consecutive series of 152 childhood acute lymphoblastic leukemias. Eur J Haematol 65:40-51 (2000).

-Bene MC, Castoldi G, Knapp W, Ludwig W, Matutes E, et al: Proposal for the immunological classification of acute leukemias. European Group for the Immunological Characterization of Leukemias (EGIL). Leukemia 9:17831786 (1995).

-Chessels JM, Swansbury GJ, Reeves B, Bailey CC, Richards SM: Cytogenetics and prognosis in childhood lymphoblastic leukaemia: results of MRC UKALL X. Medical Research Council Working Party in Childhood Leukaemia. Br J Haematol 99:93-100 (1997).

-Coccé MC, Alonso CN, Rossi J, Felice MS, Gitter MR, Gallego MS: A case of pediatric ALL with $\mathrm{t}(16 ; 21)(\mathrm{p} 11.2 ; \mathrm{q} 22)$ and FUS-ERG rearrangement. Blood Res 50:55-58 (2015).

-De Braekeleer E, Basinko A, Douet-Guilbert N, Morel F, Le Bris MJ, et al: Cytogenetics in pre$\mathrm{B}$ and B-cell acute lymphoblastic leukemia: a study of 208 patients diagnosed between 1981 and 2008. Cancer Genet Cytogenet 200:8-15 (2010).

-De Braekeleer E, Meyer C, Douet-Guilbert N, Basinko A, Le Bris MJ, et al: Identification of $M L L$ partner genes in 27 patients with acute leukemia from a single cytogenetic laboratory. Mol Oncol 5:555-563 (2011).
De Braekeleer E, Douet-Guilbert N, Morel F, Le Bris MJ, Basinko A, De Braekeleer M: ETV6 fusion genes in hematological malignancies: a review. Leuk Res 36:945-961 (2012).

Douet-Guilbert N, Morel F, Le Bris MJ, Herry A, Le Calvez G, et al: A fluorescence in situ hybridization study of TEL-AML1 fusion gene in B-cell acute lymphoblastic leukemia (1984-2001). Cancer Genet Cytogenet 144: 143-147 (2003).

Forestier E, Johansson B, Borgström G, Kerndrup G, Johannsson J, Heim S: Cytogenetic findings in a population-based series of 787 childhood acute lymphoblastic leukemias from the Nordic countries. The NOPHO Leukemia Cytogenetic Study Group. Eur J Haematol 64: 194-200 (2000).

Gallego MS, Coccé M, Bernasconi A, Felice M, Alonso C, Guitter M: Translocation $\mathrm{t}(8 ; 12)$ (q13;p13) in a case with acute leukemia of ambiguous lineage. Atlas Genet Cytogenet Oncol Haematol 12:355-357 (2008).

Gallego M, Coccé M, Felice M, Rossi J, Eandi S, et al. A new case of $t(5 ; 14)(\mathrm{q} 31 ; \mathrm{q} 32)$ in a pediatric acute lymphoblastic leukemia presenting with hypereosinophilia. Atlas Genet Cytogenet Oncol Haematol 16:183-184 (2012).

Gil EA, Lajus TB, de Moura TM, Freire JM, da Fernandes AL, et al: Banding cytogenetic analysis in pediatric patients with acute lymphoblastic leukemia (ALL) in a Brazilian population. Mol Cytogenet 6:37 (2013).

Harrison CJ, Haas O, Harbott J, Biondi A, Stanulla $\mathrm{M}$, et al: Detection of prognostically relevant genetic abnormalities in childhood Bcell precursor acute lymphoblastic leukaemia: recommendations from the Biology and Diagnosis Committee of the International Berlin-Frankfurt-Münster study group. Br J Haematol 151:132-142 (2010).

-Harrison CJ, Moorman AV, Schwab C, Carroll AJ, Raetz EA, et al: An international study of intrachromosomal amplification of chromosome 21 (iAMP21): cytogenetic characterization and outcome. Leukemia 28:1015-1021 (2014).

Heerema NA, Sather HN, Sensel MG, Lee MK, Hutchinson R, et al: Abnormalities of chromosome bands 15q13-15 in childhood acute lymphoblastic leukemia. Cancer 15:11021110 (2002).

-Heerema NA, Carroll AJ, Devidas M, Loh ML, Borowitz MJ, et al: Intrachromosomal amplification of chromosome 21 is associated with inferior outcomes in children with acute lymphoblastic leukemia treated in contemporary standard-risk children's oncology group studies: a report from the children's oncology group. J Clin Oncol 31:3397-3402 (2013).

Howlader N, Noone AM, Krapcho M, Garshell J, Miller D, et al: SEER Cancer Statistics Review, 1975-2012, National Cancer Institute. Bethesda, MD, http://seer.cancer.gov/csr/ 1975_2012/, based on November 2014 SEER data submission, posted to the SEER website, April 2015.

-Huret JL, Ahmad M, Arsaban M, Bernheim A, Cigna J, et al: Atlas of genetics and cytogenetics in oncology and haematology in 2013. Nucleic Acids Res 41:D920-D924 (2013).

ISCN (2013): An International System for Human Cytogenetic Nomenclature, in Shaffer LG, McGowan-Jordan J, Schmid M (eds) (Karger, Basel 2013).

Jeffries SJ, Jones L, Harrison CJ, Russell LJ: IGH@ translocations co-exist with other primary rearrangements in B-cell precursor acute lymphoblastic leukemia. Haematologica 99: 1334-1342 (2014).

Lemez P, Attarbaschi A, Béné MC, Bertrand Y, Castoldi G, et al: Childhood near-tetraploid acute lymphoblastic leukemia: an EGIL study on 36 cases. Eur J Haematol 85:300-308 (2010). 
Meyer C, Schneider B, Reichel M, Angermueller $S$, Strehl S, et al: Diagnostic tool for the identification of $M L L$ rearrangements including unknown partner genes. Proc Natl Acad Sci USA 102:449-454 (2005).

Mitelman F, Johansson B, Mertens F (eds): Mitelman Database of Chromosome Aberrations and Gene Fusions in Cancer (National Cancer Institute, Bethesda, 2013). http://cgap.nci. nih.gov/Chromosomes/Mitelman (assessed May 13, 2015).

Moorman AV, Ensor HM, Richards SM, Chilton L, Schwab C, et al: Prognostic effect of chromosomal abnormalities in childhood B-cell precursor acute lymphoblastic leukaemia: results from the UK Medical Research Council ALL97/99 randomised trial. Lancet Oncol 11: 429-438 (2010).

Moreno F, Schvartzman E: Registro Oncopediátrico Hospitalario Argentino (2000-2008). 3ra Edición. Ministerio de Salud de la Nación. Instituto Nacional del Cáncer. http://www. msal.gob.ar/inc/images/stories/downloads/ publicaciones/equipo_medico/ROHA/Registro_Oncopediatrico_Hospitalario_Argentino_ROHA_2008.pdf.
- Olde Nordkamp L, Mellink C, van der Schoot E, van den Berg H: Karyotyping, FISH, and PCR in acute lymphoblastic leukemia: competing or complementary diagnostics? J Pediatr Hematol Oncol 31:930-935 (2009).

Paulsson K, Johansson B: High hyperdiploid childhood acute lymphoblastic leukemia. Genes Chromosomes Cancer 48:637-660 (2009).

Roberts KG, Li Y, Payme-Turner D, Harvey RC, Yang D, et al: Targetable kinase-activating lesions in Ph-like acute lymphoblastic leukemia. N Engl J Med 371:1005-1015 (2014).

Russell LJ, Enshaei A, Jones L, Erhorn A, Masic D, et al: IGH@ translocations are prevalent in teenagers and young adults with acute lymphoblastic leukemia and are associated with a poor outcome. J Clin Oncol 32:1453-1462 (2014).

-Schneider NR, Carroll AJ, Shuster JJ, Pullen DJ, Link MP, et al: New recurring cytogenetic abnormalities and association of blast cell karyotypes with prognosis in childhood $\mathrm{T}$ cell acute lymphoblastic leukemia: a pediatric oncology group report of 343 cases. Blood 96: 2543-2549 (2000).

-Soszynska K, Mucha B, Debski R, Skonieczka K, Duszenko E, et al: The application of conventional cytogenetics, FISH, and RT-PCR to detect genetic changes in 70 children with ALL. Ann Hematol 87:991-1002 (2008).
Swerdlow SH, Campo E, Harris NL, Jaffe ES, Pileri SA, et al: WHO Classification of Tumors of Haematopoietic and Lymphoid Tissues (IARC Press, Lyon 2008).

Swirsky D, Bain B: Erythrocyte and leucocyte cytochemistry, in Lewis SM, Bain BJ, Bates I (eds): Dacie and Lewis Practical Haematolology, pp 311-333 (Churchill Livingstone/Elsevier, Philadelphia 2006).

Third International Workshop on Chromosomes in Leukemia. Chromosomal abnormalities and their clinical significance in acute lymphoblastic leukemia. Cancer Res 43:868-873 (1983).

van Dongen JJ, Macintyre EA, Gabert JA, Delabesse E, Rossi V, et al: Standardized RT-PCR analysis of fusion gene transcripts from chromosome aberrations in acute leukemia for detection of minimal residual disease. Report of the BIOMED-1 Concerted Action: investigation of minimal residual disease in acute leukemia. Leukemia 13:1901-1928 (1999).

Zhu W, Sun Z, Zhai Z, Ding K, Wu G: A novel t(3; 19)(p21;p13) in a patient with acute myelocytic leukemia. Cancer Genet and Cytogenet 179:165-166 (2007). 